\title{
Nature feature: The use of local biodiversity in science pedagogy
}

\author{
Fernan Peniero Tupas ${ }^{1,2,3}$ \\ ${ }^{1}$ Northern Iloilo Polytechnic State College, Estancia, Iloilo, Philippines. \\ ${ }^{2}$ International Research Fellow of Japan Society for the Promotion of Science, (Postdoctoral Fellowship for Research in \\ Japan - Standard). \\ ${ }^{3}$ Hokkaido University of Education, Hakodate, Hokkaido, Japan.
}

Accepted 24 July, 2019

\begin{abstract}
This research aims to utilize local biodiversity specifically Sampunong Bolo Wild Life Sanctuary in Municipality of Sara, lloilo, Philippines as teaching materials in K12 Basic Education Program Science Curriculum. The methods used were interview, photo and video elicitation, and document analysis. The highly diverse forest ecosystem in Sampunong Bolo Wild Life Sanctuary has a great potential as materials in teaching science in all grade levels according to science teachers in Northern lloilo. They were very interested and willing to utilize local biodiversity in their places as teaching materials in science. They wanted to encourage Local Government Units (LGU) to help them create teaching materials like videos and pictures to be used in their teaching but they have a negative notion about accident happen in some educational trip in the past. All science teachers were able to create an activity title. They even identified in which part of the lesson these activities will be used. The results showed that local biodiversity can be integrated into teaching science. The use of localization and contextualization is an important approach to help learners enjoy science teaching and learning. Also, this study will educate not just students but also teachers that our local biodiversity is important and most of them are now dying. Teachers must take a move to protect and preserve our local resources.
\end{abstract}

Keywords: Science pedagogy, K 12 science curriculum, local biodiversity, teaching materials, grade 3 to 10.

E-mail: fernantupas@yahoo.com.

\section{INTRODUCTION}

Pedagogy is both an art and science of teaching. In terms of science teaching, studies of Koballa (1986) and Krajcik et al. (2000) proved that inquiry learning strategies increased science achievement and cognitive development. Currently, choosing activities for particular pedagogy to enhance learning requires concern of teachers and experts. The use of various teaching procedures to different types of learners must be carefully considered (Loughran et al., 2012). Also, using pedagogical content knowledge-guided lesson study (PCKLS) in chemistry by teachers has a significant difference compared to traditional methods and students increase performance in conceptual understanding and problem-solving skills. The method was effective; thus, this study suggested that this intervention will also be used in Biology, Earth Science and Physics (Lucenario et at., 2016). Today, teachers are finding arrays of teaching strategies such as creative outputs, interactive approach, etc. to give effective approach to improve learning outcome (Bhowmik et al., 2013). With all the problems and issues concerning the implementation of the shortest basic education curriculum in the world (Tupas and Matsuura, 2011), the Department of Education (DepED) shifted to 12 years in basic education known as K12 Basic Education Program that started in 2012. However, after 7 years of the implementation of the new curriculum; the same problems such as no textbooks, lack of equipment, as well as classroom were being experienced by both teachers and students. But one unique feature of this new curriculum is encouraging teachers to use local 
resources.

In Region VI, Division of Iloilo, the low performance in the National Achievement Test (NAT) is one common problem that needs certain intervention. Based on a preliminary interview conducted by the researcher, many learners have little interest in learning science. They always find science as a difficult subject. Thus, the results of NAT for the past ten years were always below the national standard.

The goal of DepEd in NAT is a mean percentage score (MPS) of $75 \%$. This is the national standard. However, in elementary the score in $2006-2007$ was $51.58 \%$, in $2007-2008$ was $57.90 \%$, in 2008 - 2009 was $58.86 \%$, in 2009 - 2010 was $63.14 \%$, in 2010 - 2011 was $60.35 \%$ and in $2011-2012$ was $66.11 \%$. In secondary, the score science in $2004-2005,2005-2006$ and $2011-2012$ were $39.49,37.98$ and $40.53 \%$, respectively (Philippine Basic Education, 2013). This was very alarming. Science both elementary and secondary were below the national standard. The previous curriculum resulted in low performance in science due to lack of culture and insufficiency in curriculum, teaching and learning practice, instructional materials and teachers 'training (Batomalaque, ND). This low-performance attribute to teaching materials. Instructional materials in science help teachers understand his or her objective in terms of students' learning (Mishra and Yadav, 2013). Teachers with effective instructional engagement for studentproduced graduates that are involved in a scientific and professional field (Pascual, 2014). For almost 3 decades of NAT implementation, the Filipino learners have not reached the national standard score.

According to Tupas and Matsuura (2012), Filipino teachers are innovative to make science teaching fun and interesting. Currently, DepEd encourages teachers to use local resources in teaching. Localization is associated with familiarization; thus, making instruction comprehensible (Holgado, 2018). According to Garin et al. (2017), localization is about using readily accessible materials in a local setting to be used as sources for teaching and learning methodology. While contextualization is defined as accurate materials utilized by teachers inside the classroom that have relevant to learners' lives. According to Ballesteros (ND) in K12 Basic Education Program highlighted the use of localization and contextualization as new approach specifically in Science. The result of his studies revealed that using localization and contextualization increased the performance of science learners. Learning science does not only confine on four corners of the classroom but some resources can be found in surroundings or environment. Furthermore, his results revealed that localization and contextualization is the new approach in the K12 Basic Education Program of DepEd. The result of his research showed significant improvement in the performance of students in science. Besides, De Lara (2017) exposed that localized and contextualized learning materials in climate change for learners were acceptable.
Nowadays, learners experienced climate change. Therefore, there is a possibility that biodiversity can be a good source for science teaching; students have already learned many things about these florae and fauna in their lessons and as well as their experiences.

Basically, this study is about localization and contextualization. This is about using local biodiversity as teaching materials in science from Grade 3 to 10. There were various protected areas and sanctuaries in the Philippines. One of that is hidden within the vicinity of the heart of Municipality of Sara in the $5^{\text {th }}$ District of Iloilo is a nature preserve. This is declared by the Local Government Unit (LGU) Municipality of Sara, Iloilo Sampunong Bolo Wildlife Sanctuary or formerly known as Sampunong Bolo Birds Sanctuary at Barangay Juaneza. This is 52 hectares' timberland comprising of a variety of plant and animal species. The place was named Sampunong Bulo because of the abundance of Bambusa levis Blanco or synonyms to Gigantochloa levis which is locally called "Bolo". Bolo is a very thin bamboo that grows in the midlands (Tongco et al., 2016). Upon seeing lush green trees from a distance and sounds of various flying animals and running water from the entrance, the sanctuary has great potentials in many ways. No papers describing the status of the Sampunong Bolo Wildlife Sanctuary. There were studies formulated in the past but never conducted because of lack of support from concerning agencies.

Hence, this study is an informal science. Outside school premises there are many possible science ideas and concepts for students to learn. Informal science is a new field that works across a range of venues that focused on active learning (museum, after-school, programs, sciences and technology centers, media enterprises, aquariums, zoos, state parks, and botanical gardens) (Hofstein and Rosenfield, 1996). One of the most common examples of informal science in the Philippines is the Mind Museum, a project of the nonprofit Bonifacio Art Foundation, Inc. The main objective is to give extraordinary learning experiences that encourage people to understand and appreciate science in a different manner such as through dancing (Bonifacio Art Foundation, Inc. 2011). This new approach is being unveiled because the central point of this research is to gain insights about science in local biodiversity to learning fun and interesting.

According to Pinthong and Faikhamta (2018), there were a lot of science educators and researches authored and studied informal science. For instance, Finley (2012) suggested that in doing informal science education research time allotment is very important as well as the assessment before and after the activity. She also revealed that researches on informal science education must be continued for a better understanding of the role in science learning and teaching and later will be incorporated in the curriculum. Furthermore, informal science program will allow participants to experience being science practitioners, exposures with scientists, 
science educators to value the importance of science today. This will also encourage them to engage in science in general (Habig et al., 2018).

Also, "Funds of Knowledge" is also one of the agenda of this paper. This is knowledge and abilities acquired from a family and cultural background; thus, knowledge is cumulative and culturally developed. The cumulative knowledge is essential to human survival. The research will find out the backgrounds of each participant, their interest in terms of local biodiversity and for educators to integrate with science teaching and learning. The experiences in this research will help them realized that our world is abundant and diverse that can be used materials in science to make it fun and interesting. Based on the study Gonzalez et al. (2009), these experiences can help teachers formulate curriculum. Hence, this could be solutions to long-time problems in Philippine science education.

Research in science education is usually governed typically by positivist habits of investigation as proving; quantitative procedures; principles of validity and reliability; and dispassionate reporting. Thus this study also focused on two epistemologies; constructivism and interpretivism because the thrust is local biodiversity to communicate science. Constructivism was utilized as the basis by which other theories and concepts will emerge and interpretivism for the interpretation of local flora and fauna found in Sampunong Bolo Wild Life Sanctuary.

The human practices of respondents as collected data will be constructed, this is called constructivism. This philosophy of science composed of intellectual constructs based on the human experiences to build a model for the natural world (Taylor, 1996). Furthermore, Bada (2015) stated that constructivist theorist is about learning created by the students based on information and concepts are presented to them. While, interpretivism is about interpretation through of saying, explaining and translating ideas and concepts into the experience (Chowdhury, 2014). Interpretive researchers form research questions, they make fieldwork experiences and write the research report on a sense of perplexing experiences (Taylor, 1996). These were used in this paper because after the data were interpreted and found out that local biodiversity can be used as materials in teaching basic education in the Philippines. The researcher will create instructional materials in the context of local flora and fauna in all grade levels to enhance interests and eradicate notions about the difficulty in learning the subjects.

This study anchored in three different kinds of theory. These are emergent design theory, situated cognition theory and learning by doing theory. This research was about localization and contextualization; thus, emergent design theory coined by David Cavallo (Morgan, 2013) was used. This is a process of adapting to new ideas, concepts and findings derived qualitative research in teaching and learning environment. Today, the Philippine education system cannot cope with rapid technological advancement; thus, local culture is needed (Spacey, 2016). Many schools in the $5^{\text {th }}$ District of Iloilo, Philippines lacked materials and facilities in science teaching. This local resources as materials in enhancing learning is one of the trusts of DepEd. Teachers are encouraged to integrate local resources in teaching

Also, situated Cognition Theory was utilized. This is a theory that suggests learning is "naturally tied to authentic activity, context, and culture" (Brown et al., 1989). Also, this theory suggests that it is more difficult to learn from un-natural activities. For example, learning one's first language or a foreign language by immersion is widely held to be easier than learning languages from textbooks and vocabulary lists. The same is true as learning about cultural practices and scientific processes are easier done by learners when carried down into their daily activities and interests such as dancing.

Jean-Jacques Rousseau, a philosopher in 1700s explained learning by doing is to allow the teacher to present ideas to stimulate leaners curiosity because observed learning was more on memorization. John Dewey, the greatest proponent of learning by doing argued that education is life (Web, 2002). This theory is always about educational activities allowing students to discover things through relevant learning experience using their curiosity (Mutunga, 2017). Hence, educators must create a learning environment that encourages learners to utilize experiences as a vital role in acquiring knowledge and an essential element about the world (Roger, 1995).

The concepts are not new but can have good potential to enhance science instruction. This is also to help inform the community of the importance of this haven. Currently, the sanctuary is in critical conditions because of human intervention and some natural calamities that hit the area much time. Education sector can help save the flora and fauna for extinction by integrating into the science curriculum. This can also inspire students to become warriors to save and protect our environment.

Thus, the main objective of this study was to use local biodiversity in teaching science in $\mathrm{K} 12$ Basic Education Program of the Philippines.

\section{METHODOLOGY}

The study was focused on local biodiversity specifically Sampunong Bolo Wildlife Sanctuary in Sara, Iloilo, Philippines as teaching materials in science in all grade levels in the basic education program. The researcher started with documents collection taken from Municipality of Sara, Community Environment and Natural Resources Office (CENRO) in San Dionisio, and Northern lloilo Polytechnic State College in 2018. All resources collected were analyzed and evaluated to see how we can use this flora and fauna into teaching materials.

Methods used in this research were an interview, photo and video elicitation, and document analysis. A letter 
addressed to the mayor of Sara was hand-in to inform that the researcher was conducting a study of utilization of the sanctuary as teaching materials in $\mathrm{K} 12$ curriculum and to secure a permit to take pictures and video of the area. Also, a consent form was distributed to selected informants as participants of the study and the interview will be tape-recorded to capture exactly the answers.

This study was conducted in Northern $l l o i l o$ or $5^{\text {th }}$ District of the Province of Iloilo. Northern Iloilo has 11 municipalities composed of Ajuy, Balasan, Barotac Viejo, Batad, Carles, Concepcion, Estancia, Lemery, San Dioniso, Sara and San Rafael from May 2018 - February 2019. The informants of this study were Grade 3 to 10 Science Teachers and Master Teachers from mother school in Northern Iloilo and Science experts coming from SUCs in the Region were selected as informants. Specifically, purposive sampling also was employed. The informants were selected based on some characteristic, such as willing to be interviewed and knowledgeable and experience about doing instructional materials.

All the informants were interviewed using semistructured guide questions to gain rapport and trust with the informants. The guide questions were evaluated by science experts. During the interview, each informant was given 10 to 15 minutes to response all the questions. Photo and video elicitation were used in this study to show the actual situation of the sanctuary. Each teacher was given 10 to 15 minutes for their responses. They were also given time to create a possible title for a proposed activity and in what part of the lesson this will be utilized. The science curriculum guide was also analyzed.

Taped conversations were transcribed. Manual transcription was utilized in this study and done for almost a month. All the transcriptions were written in a journal. An original text in Hiligaynon and English was presented. After the data were collected, the journals were burned to ensure the identity of the informants. The researcher highlighted all the ideas and concepts about the major topics of the research. When the researcher finds the meaning segment of text in transcript, codes, and categories were assigned until the initial coding was finished. This was done for almost 1 month because the research wanted accurate results. After the data was coded, the researcher made a matrix showing major ideas and concepts. Then, these ideas and concepts were themed. Three major themes were expected to come out in this study. These new ideas and insights were included to be analyzed. Then, triangulation was done based on the interview and photo-elicitation, and documents collected from different sources.

\section{RESULTS}

\section{Sampunong Bolo as instructional material}

Table 1 summarizes the responses of the informant on local biodiversity as teaching materials in science.

Almost $90 \%$ of the informants agreed that local resources are a good source for teaching science. All of them were very happy because they were allowed to open their minds and give them knowledge on how to use local resources in teaching science.

Even one grade III science teacher said; "I am willing to do it now as long as someone will guide me. I have already ideas and concepts in mind but I don't know where to start. With all the teaching loads as well as other duties and responsibilities we have no time to do our innovations."

\section{Contents of science curriculum guide}

Table 2 summarizes the science curriculum guide where local biodiversity can be integrated into science teaching in all grade levels.

\section{Proposed activities using Sampunong Bolo wild sanctuary as teaching materials in science}

Table 3 showed the proposed activities of the informants and part of the lesson to be implemented. During the FGD, all of them work diligently. All of them showed interest in the utilization of the local biodiversity.

They agreed to conduct training about this, our probably we could have mentors from Northern lloilo Polytechnic State College (NIPSC) since they have education program. They must be experts in term of instructional materials.

Elementary science teachers concluded; "This is what we need now, DepEd does not provide us yet with the materials. Until now we do not have the textbooks. I have a Teacher's Guide and I downloaded this at the website of DepEd."

Junior high school science teacher revealed; "I spent a lot of money for printing."

Besides, one stated; "Master Teachers' duties and responsibilities are to help a teacher to find materials to improve the performance of our learners. This is a way to help the problem in having very low in NAT results."

In the output of Grade 3 Science Teachers, the picked Lesson 2 about plants and animals and the title of their work is "Getting to Know Animals and Plants in Sampunong Bolo Wild Life Sanctuary." They will use this as motivational activity on learning about contend standard parts and function of animals and importance to human and external parts of plants and their functions, and importance to human. They said for the learners to understand deeper the lessons and starts to appreciate its relationship to human, they must be aware of local resources in their respective areas.

For Grade 4, their output is "3D Model: Living Things in the Sanctuary" as Enrichment Activity. This will be used in animals and parts have body parts that make them 
Table 1. Responses of science teachers in incorporating local biodiversity in teaching science.

\begin{tabular}{|c|c|}
\hline Questions & Responses \\
\hline $\begin{array}{l}\text { What can you say about the } \\
\text { sanctuary? }\end{array}$ & $\begin{array}{l}\text { "The place is unexploited. It is so beautiful; we can bring our children to learn Science in } \\
\text { this place. They will appreciate it; the sound of the birds, the water and the wind. It's } \\
\text { perfect for instructional materials." }\end{array}$ \\
\hline $\begin{array}{l}\text { Do you have any local } \\
\text { biodiversity in your area? Did } \\
\text { you utilize this for science } \\
\text { learning? }\end{array}$ & $\begin{array}{l}\text { "I have to look for own local biodiversity and make it as materials in science. Probably, I will } \\
\text { conduct a field trip after the semester and they can write some articles about the area." } \\
\text { "We have a beautiful marine ecosystem but I don't know how to use these in science } \\
\text { teaching." }\end{array}$ \\
\hline $\begin{array}{l}\text { Do you also conduct } \\
\text { educational trip, explain your } \\
\text { answer? }\end{array}$ & $\begin{array}{l}\text { "But DepED is very strict about the field trip. With all those accidents that happen; they } \\
\text { already prohibit educational trip." } \\
\text { "I want my students to go to our mangroves, to see the century-old tree but I am scared." }\end{array}$ \\
\hline $\begin{array}{l}\text { How can you use local } \\
\text { biodiversity in your science } \\
\text { teaching? }\end{array}$ & $\begin{array}{l}\text { "I will not specifically bring my learners here but we can ask our LGU through Local School } \\
\text { Board Fund to create a movie showing the entire place or give us pictures of the area to be } \\
\text { used as materials in Ecosystem, Biodiversity and Evolution." } \\
\text { "Yes that's right, we can also use that in topic "Different kinds of Living things are found in } \\
\text { different places" like in our local biodiversity. Remember, there are beautiful places in } \\
\text { Northern Iloilo." } \\
\text { "Yes, that true especially that we don't have resources, we need to be innovative. Like in } \\
\text { the Second Quarter, we could use local flora and fauna in teaching Animals and Plants. } \\
\text { This also a way that will help them appreciate science effective because we are using local } \\
\text { knowledge." } \\
\text { "Using local resources as materials in teaching science enhance the interest of learners } \\
\text { because they know about the topic. They can also relate and can happily share something } \\
\text { based on their experience." }\end{array}$ \\
\hline
\end{tabular}

adapt to land and water. Using recycled and art materials, they will create body parts that can help animals and plants adapt to a different environment. They will use this as an enrichment activity to measure the level of understanding of the learners.

While in grade 5 , the output is called "How Plants and Animals in Local Biodiversity Produce?" This is a laboratory activity. Using their Android cellphone, the students will look for animals and plants found in the sanctuary that can be easily multiple. They will video the process. This can be used in content standard of how animals and plants reproduce.

Grade 6, they created two activities. The first one is Vertebrate and Invertebrates in Sampunong Bolo Wild Life Sanctuary, they can use this in content standards, the different characteristics of vertebrates and invertebrates. This will be used as a quiz or probably a review to assess the learnings of the students in knowing between vertebrates and invertebrates. The second activity is "A Film Showing of Interaction of Animals and Plants and Non-Living Things in Sampunong Bolo." This can be utilized in content standard, the interaction for survival among living and non-living things that take place in forests. The teachers will create this video ahead of time. They will ask help from LGU and CENRO to help them document the status of the sanctuary. This is a motivational activity.
Grade 7 have "A Journey to Untouched Ecosystem" as project, Grade 8 made "Human Impact to Hidden Treasure" as a project, Grade 9 created "Causes of Extinction of Animals and Plants in Sampunong Bolo" as essay, and Grade 10 do "How do Organisms Survive: A Documentary" as a project. The purpose of the activity according to the teachers is enhancing the skills of learners in reporting. The teachers picked the content standard, organisms interacting with each other and with their environment to survive in the Ecosystem. The students will concentrate on how these organisms interact with their environment to survive. They will create a PowerPoint presentation, then present their report in front of the class. All members should participate during the presentation.

Grade 8 teachers decided to choose the Impact of Human Activities in an Ecosystem. Nowadays, human intervention causes a great impact on our environment. They will create a poster about activities they commonly contributed that affect our ecosystem. This will be their project. The output will be posted in the school corridor to show others that we have to make a stand to help our dying environment.

During Saturday or after class, Grade 9 students will be asked to visit Sampunong Bolo Wild Life Sanctuary to have a clear view of how bountiful the sanctuary. Then, the students create an essay individually about their 
Table 2. The content per grade level and its content standard in the context of local biodiversity.

\begin{tabular}{|c|c|c|}
\hline Grade level & Content & Content standard in the context of local biodiversity \\
\hline 3 & $\begin{array}{l}\text { - Heredity: Inheritance and Variation } \\
\text { - Ecosystem }\end{array}$ & $\begin{array}{l}\text { * Demonstrate understanding of parts, and } \\
\text { function of animals. } \\
\text { * Demonstrate understanding about the } \\
\text { importance of animals to human. } \\
\text { * Identify characteristics from parents to offspring. } \\
\text { * Determine the basic needs of plants and } \\
\text { animals. }\end{array}$ \\
\hline 4 & $\begin{array}{l}\text { - } \text { Animals } \\
\text { - } \text { Plants } \\
\text { - Heredity: Inheritance and Variation } \\
\text { - Ecosystem } \\
\text { - }\end{array}$ & 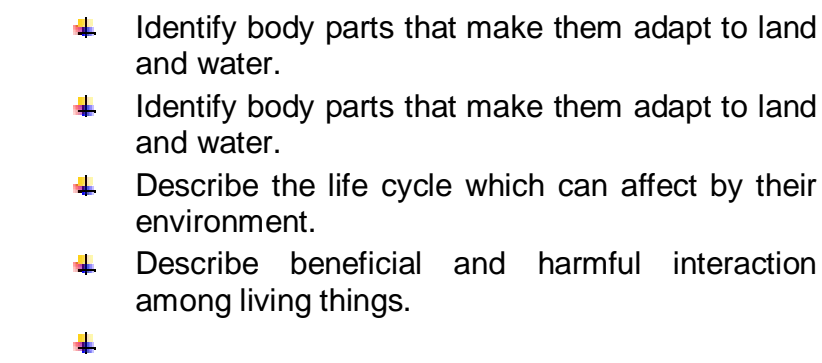 \\
\hline 5 & $\begin{array}{l}\text { - Parts and Functions } \\
\text { Animals and Plants }\end{array}$ & $\begin{array}{l}\text { * Describe the parts of the reproductive system } \\
\text { and their functions. }\end{array}$ \\
\hline 6 & $\begin{array}{l}\text { - Parts and Functions } \\
\text { Animals and Plants }\end{array}$ & $\begin{array}{l}+ \text { Determine the characteristic of vertebrates and } \\
\text { invertebrates. } \\
+ \text { Distinguish how non-flowering plants reproduce } \\
\text { * Discuss the interaction in the sanctuary. } \\
\text { * Explain the needs to protect the sanctuary. }\end{array}$ \\
\hline 7 & $\begin{array}{l}\text { - Heredity: Inheritance and Variation } \\
\text { - Ecosystem }\end{array}$ & $\begin{array}{l}\text { * Differentiate asexual and sexual reproductions of } \\
\text { flora found in the sanctuary. } \\
\text { * Describe and differentiate biotic and abiotic } \\
\text { components in the sanctuary }\end{array}$ \\
\hline 8 & $\begin{array}{l}\text { - } \quad \text { Biodiversity } \\
\text { - } \quad \text { Ecosystem }\end{array}$ & $\begin{array}{l}\text { * Classify organisms in the sanctuary using the } \\
\text { hierarchical taxonomic system } \\
\text { * Suggest ways to minimize human impact in the } \\
\text { sanctuary }\end{array}$ \\
\hline 9 & $\begin{array}{l}\text { - } \quad \text { Biodiversity and Evolution } \\
\text { - Ecosystem }\end{array}$ & $\begin{array}{l}\text { * Relate species extinction in the sanctuary } \\
\text { * Differentiate the importance of photosynthesis } \\
\text { and respiration. }\end{array}$ \\
\hline 10 & - Ecosystem & $\begin{array}{l}\text { * Explain how species diversity increased in the } \\
\text { sanctuary } \\
\text { * Suggest ways to minimize human impact in the } \\
\text { sanctuary. }\end{array}$ \\
\hline
\end{tabular}

experiences focused on extinction in Sampunong Bolo. They picked content standard, how changes in the environment may affect species extinction. They said this important since there is no policy to regulate the sanctuary. They have to create data and information to be submitted to the LGU as well as DENR.
Grade 10 used content standard, an ecosystem as being capable of supporting a limited number of organisms. They will create a document about how organisms in Sampunong Bolo survived. The whole class will be divided into a group composed of 5 to 7 members and this will serve as their project. The video will be 
Table 3. Proposed activities for integration local biodiversity.

\begin{tabular}{|c|c|c|c|}
\hline Grade level & Content standard & Activity title & Part of the lesson \\
\hline 3 & Living things & $\begin{array}{l}\text { Getting to know animals and plants in Sampunong Bolo Wild Life } \\
\text { Sanctuary }\end{array}$ & Motivational activity \\
\hline 4 & Living things & 3D model living things in the sanctuary & Enrichment activity \\
\hline 5 & Living things & How do animals and plants in local biodiversity reproduce? & Laboratory activity \\
\hline \multirow{2}{*}{6} & Living things & $\begin{array}{l}\text { Vertebrates and invertebrates in Sampunong Bolo Wild Life } \\
\text { Sanctuary }\end{array}$ & Quiz \\
\hline & Ecosystem & $\begin{array}{l}\text { Film showing of interaction of animals and plants, and non-living } \\
\text { things in the sanctuary }\end{array}$ & Motivational activity \\
\hline 7 & Ecosystem & A journey to untouched ecosystem & Project \\
\hline 8 & Ecosystem & Human impact on hidden treasure & Project \\
\hline 9 & Evolution & Causes of extinction of animals and plants in Sampunong Bolo & Essay \\
\hline 10 & Evolution & How do organisms survive: A documentary & Project \\
\hline
\end{tabular}

collected and submitted to the LGU and DENR.

\section{DISCUSSION}

The entire archipelago of the Philippine is composed of a rich and diverse ecosystem (Posa et al., 2008). Every island has unique to offer in terms of flora and fauna. Bagarinao (1997) stated that visit and first-hand experiences generate awareness about our ecosystem as well as heart towards preservation and protection of our environment. Also, Cosquer et al. (2012) revealed that in one of their conclusion on observation biodiversity was that scientific knowledge is very important because this help people about their stand on current situations of our environment. An educational trip is very important during the formative years and currently, DepED issued guidelines to ensure the safety of the students during this activity. Furthermore, the lack of science teaching materials in K12 Basic Education Program such as in grade 3 to 10 as well as in science, technology, engineering and technology (STEM) track in senior high school. This new curriculum aims to give holistic education for all, provide students ample time to master basic academic skills and participate in co-curricular and community activities (Uyquiengco, ND). Also, students are a challenge and arouse around situations and problems that will help them motivate to learn and appreciate science as a relevant and useful subject. Activities are focused to develop students' interest and let them become active learners. The use of evidence in creating explanation is learner-centered and inquiry- based; the target of DepEd for students to develop.

But one big problem in public schools in the entire archipelago, many teachers have additional responsibilities such as coaches, club and organization advisors and office staff. This is also one of the reasons that teachers have limited time to create and enhance science teaching.

Additionally, all local government units in northern lloilo should work together with all the schools to provide means for the utilization of local resources in science teaching. They need to provide support in any forms. In a way, this will help them educate students about the importance of local flora and fauna. Also, enhance interest for the preservation of our natural resources. Most especially that northern lloilo have already experienced various natural calamities.

The new science curriculum is spiral progressionlearning in an enhanced and context-based manner. The science content and science processes are intertwined. In elementary, pupils gain knowledge in areas like Biology and Earth Science. The purpose of DepEd is to ensure mastery of knowledge and skills. In junior high school, major science subjects are connected and integrated (Orbe et al., 2018). Commonly learners are greatly affected because of teacher's problems in content, pedagogy, and evaluation. Thus, the results will help DepEd together with various stakeholders to further improve the implementation of the spiral approach in science teaching.

According to Cabansag (2014), the K12 Science Curriculum will help students prepared for better work both local and abroad. But basically, this innovation will 
develop holistic skills and knowledge of students to become productive Filipino citizens. In Grade 3 to 10 the major topic is Living Things and Their Environment. In Grade 3 to 6, there are three subtopics, Living Things, Heredity: Inheritance and Variation and Ecosystem and taught in second quarter. Living things are farther divided into Humans, Animals and, Plants. Grade 7 second quarter, the major contents are Unit 1 - Parts and Functions, Unit 2 - Heredity: Inheritance and Unit 3Variation and Ecosystem. Unit 1 is divided into Microscopy, Level of Biological Organization, Animals and Plant Cells and Fungi, Protist, and Bacteria; in Unit 2, the topics are Asexual Reproduction and Sexual Reproduction; and in Unit 3, the sub-content are Components of an Ecosystem, Ecological Relationship which farther divided into Symbiotic and Non Symbiotic Relationship, and Transfer of Energy through Trophic Level. But in Grade 8 Living Things and Environment is taught in fourth quarter. The contents are Structure and Function: Focus on the Digestive, Heredity: Inheritance and Variation of Traits and Biodiversity and Ecosystem. The two contents can be the best avenue to teach the local biodiversity such as in Biodiversity we can integrate the concept in Protection and Conservation while in the Ecosystem probably in Transfer of Energy in Trophic Level, Cycling of Materials in the Ecosystem and Impact of Human Activities in an Ecosystem. Furthermore, in Grade 9 Living Things and their Environment are taught in the first quarter. We can incorporate local biodiversity in Ecosystem because the subtopic is about Flow of Energy and Matter in Ecosystem. Lastly, Grade 10, we can impart local biodiversity in Biodiversity and Evolution as well as in Ecosystem, specifically in Flow of Energy and Matter in Ecosystem, Biodiversity and Stability and Population Growth and Carrying Capacity and taught in the third quarter (Department of Education, 2013). All the topics are general; thus, teachers can integrate localization and contextualization.

This showed that we can integrate local biodiversity in our science pedagogy. Science Curriculum Guide showed that local biodiversity can be used as instructional materials in teaching the subject. There are great potentials of integrating various resources in enhancing the science curriculum. This will help teachers, as well as learners, improve the teaching and learning process. In the study of De Lara (2017) on climate change utilizing local context showed materials were acceptable because the curriculum was improved based on the needs of the learners. The developed environmental education believes to instill environmental awareness and knowledge. Besides, using authentic local indigenous data in teaching statistics can improve the effective teaching and learning approach (Garin et al., 2017).

There were many studies proved that comprehension is one factor affect students' performance in various evaluation. The National Educational Testing and
Research Center (NETRC) of DepEd provides evaluation for Grades 3, 6 and 10 called National Achievement Test or NAT (Care et al., 2015). However, for the past twodecade standardized exam were also below the national standard of $75 \%$. The low NAT results can attribute to poor preparation of teachers in science contents and pedagogy (Bernardo, 2002). Also, Nebres and Intal (1998) stated that the lack of scientific culture among Filipinos causes low performance in NAT. One of the common observations identified among learners is often they could not comprehend science lessons properly. Some of the terms used are not common; thus, impact on science learning is negative and assessment results will also be affected. The use of local resources will develop comprehension skills specifically below average.

Filipino science teachers are creative and innovative; their experiences of having limited resources and love for teaching molded them to become experts in science pedagogy. The title of activities created and part of the lessons to be implemented showed they are equipped with their subject matter. Training or workshop to enhance their knowledge and skills must be facilitated. NIPSC as a lone tertiary institution in the district and many of their faculty are experts in instructional materials must be tapped to help them on how to create resources effectively.

\section{Conclusion}

Sampunong Bolo Wild Life Sanctuary has great potential as instructional materials in teaching Science. The abundance of flora and fauna proved learners will acquire good knowledge in Living Things, Ecosystem, Biodiversity, and even Evolution. They were very interested and willing to utilize local biodiversity in their places as teaching materials in science. They wanted to encourage Local Government Units (LGU) to help them create teaching materials like videos and pictures to be used in their teaching but they have a negative notion about accident happen in some educational trip in the past. All science teachers were able to create interesting topics. They even identified in which part of the lesson these activities will be used. The use of localization and contextualization is an important approach to help learners enjoy science but additional duties and responsibilities of teachers stopped them from creating innovations. Also, this study will educate not just students but also teachers that our local biodiversity is important and most of them are now dying. Teachers must take a move to protect and preserve our local resources. They want to help their students especially below-average learners. The enthusiasm of the science teachers, as well as their perseverance and determination showed a positive aspect that they are willing to utilize local resources in science education. Thus, the support of the national government, LGU, and school management 
must be given importance effectively.

\section{ACKNOWLEDGEMENT}

This work was supported in part by JSPS KAKENHI Grant Number 19F19014. Furthermore, the researcher would like to extend his heartfelt gratitude to Dr. Lourdes $\mathrm{N}$. Morano and Dr. Harold O. Buenvenida for taking the time to evaluate this study.

\section{REFERENCES}

Bada, S. O. (2015). Constructivism learning theory: A paradigm for teaching and learning. IOSR Journal of Research and Method in Education, 5(6): 66-70.

Bagarinao, T. (1997). Nature parks for environment education and biodiversity conservation in the Philippines. SEAFDEC Asia Aquaculture, 19(3): 8-30.

Ballesteros, J. (ND). Localization and Contextualization of Science Activities in Enhancing Learners' Performance. Retrieved March 11, 2019 from https://www.academia.edu/26424467/Localization_and_ Contextualization_of_Science_Activities_in_Enhancing_Learners_Pe rformance.

Batomalaque, A. (ND). Basic Science Development Program of the Philippines for International Cooperation. Retrieved March 23, 2019 from http://www.criced.tsukuba.ac.jp/pdf/09_Philippines_Antonio.pdf.

Bernardo, A. B. I. (2002). Teachers, the problem of learning and reform in math and science education. Ateneo de Zamboanga Journal of Multidisciplinary Studies, 2(1): 1-20.

Bhowmik, M., Banerjee, B. and Banerjee, J. (2013). Role of pedagogy in effective teaching. Basic Research Journal of Education Research and Review, 2(1): 1-5.

Bonifacio Art Foundation, Inc. (2011). The Mind Museum. Retrieved July 12, 2019 from http://www.themindmuseum.org/about-us/2/aboutus.

Brown, J. S., Collin, A., and Duguid, P. (1989). Situated cognition of culture of learning. Educational Research, 18(1): 32-42.

Cabansag, M. G. S. (2014). Impact statements on the K12 science program in the enhanced basic education curriculum in provincial school. Journal of Arts, Science and Commerce, 1(2): 29-39.

Care, E., Azim, F., Beswick, B., Hardeg, S. M., and Lou, R. (2015). Review of large-scale assessment for use in the Philippines. Assessment, Curriculum and Technology Research Center, A Partnership between the University of Melbourne and the University of the Philippines, supported by the Australian Government. Retrieved May 27, 2019 from https://actrc.org/projects/review-oflarge-scale-assessments-for-use-in-the-philippines/.

Chowdhury, M. F. (2014). Interpretivism aiding our understanding of the contemporary social world. Open Journal of Philosophy, 4: 432438.

Cosquer, A., Raymond, R., and Prevot-Julliard, A.C. (2012). Observation of everyday biodiversity: a new perspective for conservation? Ecology and Society, 17(4): 2.

De Lara, K. A. (2017). Contextualization and localization: acceptability of the developed activity sheet in science 5 integrating climate adaptation. Proceeding of the International Conference on Climate Change, 1: 20-24.

Department of Education (2013). K to 12 Curriculum Guide - Science (Grade 3 to 10). Department of Education, DepEd Complex, Meralco Avenue, Pasig City, Philippines.

Finley, L. (2012). The Effect of an Informal Science Education Settings on Students' Attitudes towards Learning Science. The University of Southern Mississippi - The Aquila Digital Community.

Garin, R. M., Reyes, R., Domantay, G. F., and Rosal, J. (2017). Contextualized and localized as a Technique in Teaching Basic Statistics. Asia Pacific Journal of Education, Arts and Science, 4(1): $62-67$.
Gonzalez, N., Moll, L. C., Floyd-Tenery, M., Rivera, A., Rendon, P., Gozalez, R. and Amanti, A. (2009). Teacher Research on Funds of Knowledge: Learning from Household. Educational Practice Report: 6. National Center of Research on Cultural Diversity and Second Language Learning.

Habig, B., Gupta, P., Levine, B., and Adams, J. (2018). An Informal Science Program: Impact on STEM Major and STEN Curriculum Outcome. Science Research Education. https://doi.org/10.1007/s11165-018-9722-y.

Hofstein, A., and Rosenfield, S. (1996). Bridging the gap between formal and informal science learning. Studies in Science Education, 29: $87-112$

Holgado, M. T. (2018). Why K12 Learners Need Contextualization and Localized Instruction. Depedbataan.com Publication. The Official website of DepEd Division of Bataan.

Koballa, T. R., Jr. (1986). Teaching hans-on science activities: Variables that moderate attitude-behavior consistency. Journal of Research in Science Teaching, 23(6): 493-502.

Krajcik, J., Marx, R., Blumenfield, P. Soolway, E. and Fishman, B. (2000). Inquiry-based science supported by technology: Achievement among urban middle school students. Ann Arbor, Ml: University of Michigan School Education.

Loughran, J., Berry, A., and Mulhall, P. (2012). Understanding and developing science teachers' pedagogical content knowledge. Retrieved June $30, \quad 2019$ from https://www.researchgate.net/publication/318586604_Understanding _and_developing_science_teachers'_pedagogical_content_knowledg $\bar{e}$.

Lucenario, J. L. S., Yangco, R., Punzalan, A. E. and Espinosa, A. A. (2016). Pedagogical content knowledge-guide lesson study: effect on teacher competence and students' achievement in chemistry. Educational Research International, 1-9.

Mishra, S. R. and Yadav, B. (2013). Use of teaching learning materials in science at upper primary school in Mandeshwar Khargone (Madhya, Pradesh): An analysis. International Journal of Scientific and Engineering Research, 4, 2.

Morgan, D. L. (2013). Emergent Design. The SAGE Encyclopedia of Research Methods.

Mutunga, D. (2017). Learning by Doing. Dewane Mutiunga, Retrieved March 28, 2019 from https://dewanemutunga.com/learning-by-doing/.

Nebres, B. F., and Intal, A. M. G. (1998). The challenge of developing science culture in the Philippines. In E. B. Ogena and F. G. Brawner (Eds.). Science Education in the Philippines: Challenges for development (29-40). Taguig Metro Manila: NAST, SEI, UP-CIDS.

Orbe, J. R., Espinosa, A. A., and Datukan, J. T. (2018). Teaching chemistry in a spiral progression approach: Lessons from science teachers in the Philippines. Australian Journal of Teacher Education, 43: 17-30.

Pascual, N. T. (2014). Impact of mathematics and science instructional practices, curriculum and academic achievement to career choice of laboratory school graduates at University of Rizal System - Morong. International Journal of Science: Basic and Applied Research, 15(1): 397-415.

Philippine Basic Education (2013). The National Achievement Test in the Philippines. Retrieved December 12, 2018 from https://www.philippinesbasiceducation.us/2013/07/the-nationalachievement-test-in.html.

Posa, M. R. C., Diesnos, A. C., Sadhi, N. S., Brooks, T. M. (2008). Hope for threatened tropical biodiversity: Lessons from the Philippines. BioScience, 58(3): 231-240.

Roger, S. C. (1995) What We Learn When We Learn by Doing. (Technical Report No. 60). Northwestern University, Institute for Learning Sciences.

Spacey, J. (2016). What is Emergent Design? Retrieved January 29, 2019 from https://simplicable.com/new/emergent-design.

Taylor, P. C. (1996). Constructivism and Interpretive Research. WordPress.Com. Retrieved December 12, 2018 from: http://pendidikansains.wordpress.com/2008/04/18/constructivismand-interpretive-research/.

Tongco, J. V., Mun, S. P., Abasolo, W. and Razal, R. (2016). Mineral, nutritional, and phytochemical profile, total phenolic content, and radical scavenging activity of Philippines bamboo "Bolo" 
Gigantochloa Levis (Blanco) Merr leaves. Natural Product Science, 22(1): 60-66.

Tupas, F. P., and Matsuura, T. (2011). Comparative studies of science education curricula between Japan and the Philippines. The Journal of School Education Society of Hakodate, 16(3): 13-22.

Tupas, F. P., and Matsuura, T. (2012). A comparative study of science lessons in elementary and secondary education in Japan and the Philippines. Journal of Hokkaido University of Education, 62(2): 8794.

Uyquiengco, M. (ND). Benefits of the K-12 curriculum for Filipino students! Retrieved March 11, 2019 from https://ph.theasianparent. com/advantages-new-k-12-curriculum.

Web, F. (2002). Jean Jacques Rousseau 1712-78, Learning through Experiences. Retrieved May 23, 2019 from http://www.froebelweb. org/web7003.html.
Citation: Tupas, F. P. (2019). Nature feature: The use of local biodiversity in science pedagogy. African Educational Research Journal, 7(3): 153-162. 